\title{
Thoughts on "Red Culture" Running Through the Ideological and Political Education of College Students
}

\author{
Zhenrong Zhang \\ Science and Technology College Gannan Normal University \\ Ganzhou, China 341000
}

\begin{abstract}
Under the influence of today's impetuous social reality, college students ignore politics. The ideological consciousness is getting worse. For the learning, college students become more and more incapable of doing what they should do. The enthusiasm of the older generation seems to be farther and farther away from us. This is undoubtedly a very dangerous signal. This paper takes the red culture as a means of consultation. The college students can feel the essence of the "red culture" formed by the Chinese Communist Party in the arduous and magnificent struggle process. The students can strengthen their beliefs, distinguish the right from the wrong, clearly define their mission, and actively participate in the construction of the society with Chinese characteristics.
\end{abstract}

Keywords-college students; red culture; ideological education

\section{INTRODUCTION}

Red culture is an advanced culture with Chinese characteristics created by the Chinese Communists, advanced elements and the people in the revolutionary war era, which contains rich revolutionary spirit and profound historical and cultural connotations. The magnificent historical process of the Chinese revolution, the tremendous achievements of the revolutionaries, and the thrilling scenes of the old revolutionary sites and relics will always be the best subjects to move and educate future generations. Exploring and utilizing the unique value function of red culture is not only conducive to adhering to the practicality of socialist core value system, but also plays an important role in promoting the creation of new brands of red cultural industry with Chinese characteristics and world influence. In this way, it is an important subject for the ideological and political education of college students in the new era to make college students feel the essence of the "red culture" formed by the arduous and magnificent struggle of the Communist Party of China, and to help them firm their beliefs, distinguish right from wrong, and clarify their mission.

\section{CURRENT Situation OF COLlEGE Students THINKING AND EXISTING PROBLEMS}

Under the impact of multiculturalism and impetuous hearts, many college students are eager for success. They don't have enthusiasm for learning, don't have goals, and don't have struggle spirit or firm ideals and beliefs. The style of life is sloppy and the state of mind is decadent. In the university, they seem to be busy. However, they don't know what to do. The author conducted a preliminary survey of college students through the Internet. The 1856 college students who sent feedback came from universities and colleges across the country, including many graduate students. Through data compilation, the author finds that the current ideological status of college students generally has the following problems:

\section{A. Some Bias in Ideological and Moral Understanding of College Students, Lacking the Sense of Justice}

According to the survey, $56.7 \%$ of the students believe that the current "fake, evil and ugly" is more than "truth, kindness and beauty", while those who believe that "truth, kindness and beauty" is more than "fake, evil and ugly" only accounts for $9.8 \%$. 33.5\% of college students don't have clear views. "There are many things that people don't know whether it is good or bad." It is unbelievable that almost everyone accepts the social reality they believe and even proposes the principle "the survival of the fittest".

\section{B. In the Social Reality of Diversified Life Values, It Is Impossible to Find Its Own Position}

College students have many desires, facing various interests driven by the development of the market economy. The world outlook, outlook on life and values of college students are uncertain. They expect the future, and they are also afraid of the future. Can they surpass the glorious oneself in the past? Can college students find new glory in the future and new oneself? Do college students believe in collectivism or individualism? Shall college students focus on dedication or requirements? Shall they choose to serve others or help themselves? Shall college students study hard or pursue money, enjoyment, excitement, comfort and leisure? According to the survey, more than $60 \%$ of college students are at a loss in their choice of their own values, forming an emptiness of ideals. 


\section{Lacking Good Volitional Quality}

"Learning knowledge and reserving capacity" is the fundamental task and ultimate goal of college students during their school years. It is the foundation for the success in the society. The good volitional quality is the prerequisite for college students to effectively learn knowledge and reserve capacity. However, in the online survey, when asking the question "what do you lack during the learning process?", 53.6\% of the college students answer that "they are weak and impetuousness in the learning. The college students have dependence, impulsivity and indecision, lacking perseverance, inertia, etc.

\section{Poor Ability to Practice Public Morality}

In the analysis of the data on the practice of public morality, the author finds that among the 1856 college students who reported feedback, less than $20 \%$ of the students show good moral literacy. In the electronic questionnaire, there is a question that "when seeing the old, weak, pregnant, and disabled people on the bus without having a seat in your daily life, what is the first reaction? When seeing people spite or throw the rubbish on the ground, what is the first reaction?" Nearly $40 \%$ of the students answer: "It is normal". More than $30 \%$ of the students answer: "This can be understood." Less than $20 \%$ of the students answer: "It is not suitable for the identity of college students."

\section{E. The Helpless Transformation from the Longing of "Ignorant Freshmen" to Escaping the Pursuit of Reality or Responsibility for Life}

According to the survey data, the most passionate time in the university is the time the freshman just entered the school. Many senior college students define the freshman as "ignorant college students". Entering the school, the freshmen have full hope and beautiful life ideals. However, in the sophomore year, many students began to be assimilated by the realization of the big environment, began to enjoy the entertainment of the university, and obsessed with the virtual network world. Since then, as time goes by, many college students feel the pressure of the future. They begin to be anxious, fearful and confused. Such a state of fear and anxiety makes them escape the reality and life responsibility step by step.

\section{RESEARCH STATUS AND SIGNIFICANCE OF "RED CulturE" RunNing Through IDEOLOGICAL EDUCATION OF COLLEGE STUDENTS}

At present, there are very few researches on the "red culture" in Western countries. Only a few Western scholars have opinions on the "red", "revolution", "Marxist culture" and other vocabularies related to Chinese "political movement". American political scientist Elizabeth J. Perry puts forward that the red culture before liberation should be "cultural mobilization" historical movement of cultural positioning in the article "Red Culture and Chinese Revolutionary Tradition - Talk between Yu Jianrong and ElizabethJ.perry". American scholar Hong Changtai proposes in the "Red Route: Creating a Museum of Chinese Revolutionary": building a "Red Museum" reflects the attempt of the Communist Party of China to control the nationality of collective memory and the history of monopoly manufacturing.

The content of ideological and political education of western college students mainly includes political education, moral education, legal education, and religious education, etc. Among them, political education is mainly carried out through political socialization or civic education. In the West, due to adopting multi-party system and universal suffrage system, each different political party have different opinions and have formed different political ideologies. In order to win in the election, each political party will adopt different means and methods to influence and educate citizens to accept their political ideology. Its ideological and political education will include diversified content.

In China, the study of red culture is extensive and indepth. Combining the red culture with the study on ideological and political education of college students, Liu Mingtao puts forward in the article "On the role of red culture in the ideological and political education of college students" that red culture is an important part of advanced socialism culture. The red culture is a cultural form that can be integrated into the classroom and extracurricular practice, while deepening the minds of college students and touching their souls. Zhou Haiyan proposes in "study of the effective use of red resources in the ideological and political education of college students". The red resource is valuable asset created by the Communist Party of China in the practice of revolution, construction, reform and development. It contains the revolutionary spirit of loving one's country and people, firm belief, hard work and innovation. It reflects the Chinese national spirit. It is an educational resource that cannot be ignored in the ideological and political education of college students. Guo Shaohua puts forward in the "value and approach of the integration of red culture into the ideological and political education of college students" that the red culture contains huge ideological and political education value and has strong moral education function. For contemporary College students, it plays good education and vigilance role. Chen Gang proposes in "Research on Red Film Culture and College Students' Ideological and Political Education" that culture is the blood of a nation and the spiritual home of the people. As a cradle for cultivating high-quality talents, colleges and universities must adhere to the spirit of "Sixth Plenary Session of the Seventeenth Central Committee", adhere to the development path of socialist culture with Chinese characteristics, and strive to build a socialist cultural country and promote the building of a socialist core value system. We can make full use of the red culture. Especially, the red film and television culture guides the society, educates the people, improves the development, and promotes the ideological and political work and the construction of campus culture in colleges and universities.

In the process of ideological and political education of contemporary college students in China, Marxist scientific world outlook and methodology, outlook on life and values, 
socialism, collectivism, patriotism and party line, guidelines and policies are its core system. The red cultural resources carry rich historical changes and profound cultural connotations, reflecting the lofty thoughts, firm beliefs, patriotism and noble qualities of the revolutionary ancestors. It covers all the contents of the ideological and political education of Chinese college students. Under the influence of today's impetuous social reality, college students don't talk about politics, and the thoughts are getting lower and lower. For the learning, college students can't calm down to do what they should do. The enthusiasm of the older generation seems to be getting farther and farther away from us. It is a very dangerous signal. At this time, red culture running through the political and ideological education of college student has strong pertinence and far-reaching practical significance.

\section{IV. "Red Culture" Runs Through The}

CONSTRUCTION OF THE IDEOLOGICAL AND POLITICAL EDUCATION PRACTICE PlatForM FOR COLLEGE STUDENTS

\section{A. Main Contents}

Taking the analysis of contemporary college students' ideological status and existing problems as the starting point, the colleges and universities should introduce red resources, and deepen the ideological and political education of college students with red culture. The main research contents are as the followings:

- The connotation and importance of red culture. Through the core value system of red culture, it extracts moral education value that keeps pace with the times;

- Analyzing the current situation of ideological and political education for contemporary college students, specifically: 1 the current situation of college students' ideological and political education; 2 the problem of college students' ideological and political education; 3 the influence of various cultures on college students' thoughts;

- The positive significance of red culture on college students' ideological and political education;

- Related countermeasures to deepen the current ideological and political education of college students with red culture.

\section{B. Basic Ideas and Methods}

Based on management science, the colleges and universities should take the ideological and political education, sustainable development theory, systematic science theory, etc. as the guidance, and adhere to the combination of theoretical analysis and empirical analysis, qualitative analysis and quantitative analysis. Based on the literature review and the investigation of the current situation of college students' thoughts, the author makes the research on the first content of this topic. That is the connotation and importance of red culture, and to explore the value function of moral education in the core value system of red culture. On this basis, combined with the previous research results, we can establish correct guiding ideology. College students adhere to the guiding ideology of Marxism-Leninism, Mao Zedong Thought, Deng Xiaoping Theory and the important thinking of the "Three Represents", the scientific development concept and the historical mission of young college students shouldering the Chinese dream. There are a series of practical research work to promote and deepen the ideological and political education of college students with red culture in the campus:

- The content that the teachers and students love to see is the theme. They will sing red songs, listen to red stories and do many other things.

- The music department takes the lead in hosting the "Red Song Competition", which sets off the wave of learning red songs and singing red songs in the school. It allows students to commemorate the revolutionary ancestors in singing, and inspires revolutionary fighting spirit. Thus, college students receive vivid education.

- The school propaganda department establishes a "red website", such as "red culture baptizing body and mind", making red culture a new and energetic force for the ideological and political education.

- When teaching ideological and political education, the teachers teach students more red cultural ideas, improving ideological and political education.

- The colleges and universities organize students to visit the red cultural and educational resources such as memorial halls, revolutionary sites, museums, etc., and hold a meeting on the sense of the red culture.

- The colleges and universities organize red book rafting activities in schools, allowing the students to have thought exchange and learn from each other. It will form a platform for the red culture.

- The colleges and universities establish a management organization for red culture in units of departments (schools) or classes to promote students' ideological exchanges and learn more about red culture.

- The colleges and universities conduct a "red story" speech contest in the school. College students can deeply feel the profound content of the red culture.

- The colleges and universities organize and arrange regular condolences to the older generation of revolutionaries, and improve the patriotic sentiments of college students through communicating with revolutionary ancestors.

- Through the political classroom, theme class meetings, broadcasting, practical activities, and the broadcast of revolutionary films, the colleges and universities will strengthen the red cultural education for college students. College students correct their own attitudes of study and life, further enhance 
themselves and improve their thinking. This is good for political education.

\section{CONCLUSION}

Taking the red culture of rich cultural transformation and profound cultural connotation as an educational platform, college students can relive the lofty thoughts, firm beliefs, patriotism and other noble qualities of the revolutionary ancestors. It will deepen related countermeasures for current college students' ideological and political education with red culture, and encourage college students to seriously study and carry forward the red spirit. The college students draw rich cultural essence from it. It can realize its value. Red spirit burning in the university campus likes "the fire of the stars". Guided by systematic science theory, this paper absorbs a large number of existing research results, and deepens the investigation of the current situation of college students' thinking. From the perspective of combining theory with practice, macro and micro, this paper uses literature research method (using books, newspapers, magazines, networks, etc. to collect relevant information), investigation and research method (carrying out questionnaires, interviews, etc. to obtain firsthand information) to carry out effective construction of a practical platform. It has strong pertinence and far-reaching reality to deepen the ideological diagnosis and treatment of college students.

\section{REFERENCES}

[1] Ye An, Liu Lin. A brief discussion on the cultivation of red culture and contemporary artisan spirit in vocational colleges[J]. Technical Education Forum, 2015(12)

[2] He Qixin, Xiang Guohua, Yu Xueyuan. Application of red cultural resources in cultivating socialist core values[J]. Jiangxi Social Sciences, 2013(10).

[3] Wang Lixia. The Value and Realization of Red Cultural Resources in College Students' Ideological and Political Education-Taking red culture education in colleges and universities in jiangxi province as an example[J]. Ideological Education Research, 2010(07).

[4] Guo Huasheng, Zhang Hua, Liu Shanfa. Integrating Red Culture into College Ideological and Political Education-Based on the analysis from multidimensional perspectives[J]. Journal of the Party School of Shanxi Provincial Committee of the Communist Party of China, 2015(02). 